\title{
Residues of chlorinated hydrocarbon insecticides in the North Sea environment
}

\author{
Jan H. Koeman, Jan Veen, Eduard Brouwer, \\ Leontine Huisman-de Brouwer and Jan L. Koolen \\ Institute of Veterinary Pharmacology and Toxicology of the University of Utrecht, \\ Utrecht, The Netherlands, \\ and \\ Government Institute of Sewage Purification and Industrial Waste Treatment, \\ Voorburg, The Netherlands
}

\begin{abstract}
KURZFASSUNG: Rückstände von chlorierten Kohlenwasserstoff-Insektiziden im Lebensraum der Nordsee. In einer großen Brutkolonie von Brandseeschwalben (Sterna sandvicensis) auf der Insel Griend im holländischen Wattenmeer war die Anzahl der Brutvögel von $>20000$ Paaren im Jahre 1955 auf etwa 1000 Paare im Jahre 1965 zurückgegangen. Viele Vögel wurden tot oder sterbend mit Krampfsymptomen aufgefunden. Organe und Blut dieser Vögel wurden auf ihren Gehalt an nerventoxischen Stoffen, insbesondere an chlorierten Kohlenwasserstoff-Insektiziden, untersucht. Die Konzentrationen wurden mit denen von Jungvögeln verglichen, die im Laboratorium auf künstliche Weise mit diesen Stoffen versehen worden waren und daran auch starben. Es konnte somit nachgewiesen werden, daß die in den Brandseeschwalben gefundenen Konzentrationen zum Tod der Tiere geführt haben. Die an verschiedenen Orten gesammelten Eier der Brandseeschwalben wurden ebenfalls untersucht. Fier aus den Niederlanden und aus Deutschland enthielten deutlich mehr Endrin, Dieldrin und Telodrin als Eier aus England und Irland. Verschiedene Fischarten (Clupea sprattus, Clupea barengus, Ammodytes lanceolatus), die von den Brandseeschwalben gefressen werden, wurden im holländischen Wattenmeer gesammelt und analysiert; sie enthielten beträchtliche Mengen an chlorierten Kohlenwasserstoff-Insektiziden. Der Herkunft dieser Stoffe wurde durch Untersuchungen von Miesmuscheln (Mytilus edulis) nachgegangen, die an verschiedenen Stellen entlang der holländischen Küsten gesammelt wurden. Die größten Insektizid-Konzentrationen wurden in Miesmuscheln gefunden, die aus dem Gebiet der Rheinmündung stammten. Einem dort gelegenen chemischen Werk, das diese Insektenvertilgungsmittel herstellt, wurden die Untersuchungsergebnisse mitgeteilt. Zugleich wurden geeignete Maßnahmen vorgeschlagen, um das Einleiten von insektizidhaltigen Abwässern zu verhindern. Augenscheinlich hat inzwischen die Konzentration einiger dieser Stoffe in Mytilus edulis abgenommen.
\end{abstract}

\section{INTRODUCTION}

In 1964 residues of a number of chlorinated hydrocarbon insecticides were discovered in Sandwich terns (Sterna sandvicensis) and spoonbills (Platalea leucorodia), which were seen dying or found dead at the island of Texel in the Dutch Wadden Sea (Koeman \& Genderen 1965, 1966). The symptoms, tremors and convulsions, suggested that the birds were poisoned, probably by neurotoxic compounds. 
A detailed study was made in the Sandwich tern colony at the island of Griend in the Wadden Sea, covering the breeding periods in 1965 and 1966, in order to determine the toxicological significance of the mentioned insecticide residues. The colony on this island had decreased in numbers from more than 20.000 pairs about ten years ago, to less than 1000 pairs now.

Also fish were caught in the Wadden Sea, of the kind which served as food for the terns: sprat (Clupea sprattus), juvenile herring (Clupea harengus) and sand-eel (Ammodytes lanceolatus).

Both terns (issues and eggs) and fish were analysed for their contents of chlorinated hydrocarbon insecticides with the help of gas-liquid chromatography, supplemented with thin-layer chromatography.

\section{RESULTS AND DISCUSSION}

In 1965 mortality was observed in Sandwich terns of different age classes: pulli, older young birds and adults. In the laboratory it had been found, that chickens of hens, newly hatched from eggs containing amounts of dieldrin dosed artificially, contain this compound mainly in the tissues. During the first two days, however, these chickens were not yet fed, and had to use their reserve fat. The insecticide present in this came free into the blood, and under certain circumstances caused the death of the animals (Koeman et al. 1967a). From a comparison of the residues found in the organs and blood of the Sandwich terns with those in the experimentally poisoned chickens, it could be concluded that insecticides were indeed responsible for the death (KOEMAN et al. 1967b).

In nature this indirect intoxification was observed not only in pulli, but also in older young birds, especially after a period of bad weather during which it was impossible to get food. Even in adult birds this phenomenon has been observed. For example, female eider ducks (Somateria mollissima), which have a breeding colony on

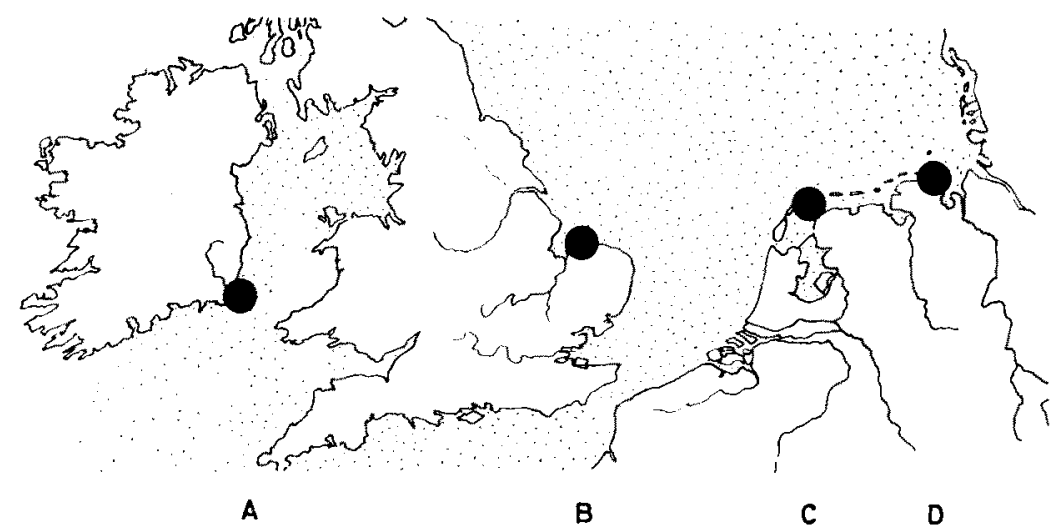

Fig. 1: Locations where tern eggs were sampled. A: Wexford, Ireland; B: Scolt Head, England; C: Griend, The Netherlands; D: Oldeoog, Germany 
several of the Dutch Wadden islands and feed almost entirely on sea-organisms in this area, died on their nests during the breeding period. If breeding, they do not feed for some weeks, and it has been found that the concentration of insecticides in the blood increased 20 -fold during this period.

In 1966 the mortality of the Sandwich terns observed in the previous years failed to occur. This could be correlated with a decline in the tissue levels of telodrin and dieldrin, both in birds and fishes. For example, the results for fish are presented in Table 1.

The environmental contamination was studied in a broader scope by comparison of the residues in the eggs of different tern species, sampled in Ireland, Great Britain, The Netherlands and Western Germany (Fig. 1).

The results, presented in Table 2, show that there is a marked difference qualitatively as well as quantitatively, between Ireland and Great Britain on one hand, and The Netherlands and Western Germany on the other.

The distribution of the insecticides in the Dutch and West Germany coastal environment was studied further by using the mussel (Mytilus edulis) as indicator

Table 1

Residues of chlorinated hydrocarbon insecticides in sprat (Clupea sprattus), juvenile herring (Clupea harengus) and sand-eel (Ammodytes lanceolatus), captured in the Dutch Wadden Sea in 1965 and 1966. DDE could not be determined accurately because of interferences by other compounds with the same chromatographic characteristics. In Sweden it has recently been found, that these compounds might consist of polychlor-biphenyl, PCB (Report on a new chemical hazard 1966)

\begin{tabular}{|cccccc|}
\hline Year & $\begin{array}{c}\text { Number } \\
\text { of fishes }\end{array}$ & $\begin{array}{c}\text { Residue in ppm of body weight } \\
\text { dieldrin }\end{array}$ & $\begin{array}{c}\text { (geometric mean and ranges) } \\
\text { telodrin }\end{array}$ & endrin & DDE \\
\hline 1965 & 103 & 0,27 & 0,05 & 0,14 & $<0,12$ \\
& $(11$ samples) & $(0,16-0,42)$ & $(0,04-0,07)$ & $(0,07-0,45)$ & $(0,10-0,15)$ \\
1966 & 37 & 0,07 & 0,02 & 0,09 & $<0,10$ \\
& $(28$ samples $)$ & $(0,01-0,23)$ & $(0,01-0,05)$ & $(0,01-0,29)$ & $(0,04-0,23)$ \\
\hline
\end{tabular}

Table 2

Residues of chlorinated hydrocarbon insecticides in the eggs of different Sterna species, sampled in Ireland (Wexford), Great Britain (Scolt Head), The Netherlands (Griend) and West Germany (Oldeoog). DDE see comment in Table 1

\begin{tabular}{|c|c|c|c|c|c|c|c|c|c|}
\hline \multirow{2}{*}{$\begin{array}{c}\text { Sampling } \\
\text { place }\end{array}$} & \multirow{2}{*}{$\begin{array}{c}\text { Year } \\
1965\end{array}$} & \multirow{2}{*}{ Species } & \multirow{2}{*}{$\begin{array}{c}\begin{array}{c}\text { Number } \\
\text { of eggs }\end{array} \\
5\end{array}$} & $\begin{array}{c}\text { diel } \\
\text { mean }\end{array}$ & $\begin{array}{l}\operatorname{Re} \\
\text { drin } \\
\text { max. }\end{array}$ & $\begin{array}{l}\text { esidue in ppm } \\
\text { telodrin } \\
\text { mean max. }\end{array}$ & $\begin{array}{c}\text { of total wei } \\
\text { endrin } \\
\text { mean max. }\end{array}$ & mean & $\begin{array}{l}\mathrm{DE} \\
\text { max. }\end{array}$ \\
\hline & & & & 0,12 & 0,15 & not detect. & not detect. & 0,64 & 0,97 \\
\hline Wexford & 1965 & S. dougalli & 6 & 0,05 & & not detec & not detec & 0,24 & \\
\hline Scolt H. & 1965 & S. sandvicensis & 5 & 0,15 & 0,21 & not detect. & n.d. $\quad 0,03$ & 0,41 & 0,49 \\
\hline Griend & 1965 & S. sandvicensis & 8 & 0,80 & 2,4 & $0,09 \quad 0,45$ & $0,17 \quad 0,34$ & 0,61 & 1,22 \\
\hline Oldeoog & 1965 & S. birundo & 14 & 0,70 & & 0,08 & 0,24 & 0,54 & \\
\hline Griend & 1966 & S. sandvicensis & 25 & 0,23 & 0,79 & $0,06 \quad 0,12$ & $0,20 \quad 0,36$ & 0,61 & 1,11 \\
\hline Oldeoog & 1966 & S. birundo & 6 & 0,29 & & 0,06 & 0,08 & 0,44 & \\
\hline
\end{tabular}


organism. This choice was based on work in the United States with oysters, where it had revealed that lamellibranchiate molluscs concentrate chlorinated hydrocarbon insecticides as a consequence of their filter-feeding habit (BUTLER 1966).

In August 1965 mussels were sampled at about 20 places alongside the Dutch coast. The residues of chlorinated hydrocarbons proved to be highest near the mouth of the river Rhine, and on places North East of this. This corresponds with the outflow of the river water into the sea: it moves alongside the Dutch coast in a North East direction, and enters the Wadden Sea.

The samples were shown to contain telodrin, an insecticide not used in Europe. It is or was manufactured, however, by a chemical industry near the mouth of the river Rhine. It was very likely that the telodrin originated from this plant, by means of its effluents. It is of interest to note, that in August 1964 an explosion took place in the factory, with loss of a large amount of telodrin into the environment (Telodrin intoxicaties 1965).

In the summer of 1966 the mussels were sampled at 5 places North East of the mouth of the river Rhine. From the results shown in Table 3 it can be concluded that the insecticide residues now again were highest at the location nearest to the river (Scheveningen) and declined in a Northern direction.

Table 3

Residues of chlorinated hydrocarbon insecticides in mussels (Mytilus edulis) sampled at different places alongside the Dutch and West German coast, and at one place on the Britain coast (Fig. 1), during summer 1966. DDE see comment in Table 1

\begin{tabular}{|lcccc|}
\hline $\begin{array}{c}\text { Sampling } \\
\text { place }\end{array}$ & dieldrin & $\begin{array}{c}\text { Residue in ppm of body weight } \\
\text { telodrin }\end{array}$ & endrin & DDE \\
\hline Schereningen & 0,10 & $<0,003$ & 0,36 & $<0,04$ \\
Katwijk & 0,02 & $<0,001$ & 0,07 & $<0,02$ \\
IJmuiden & 0,04 & $<0,001$ & 0,01 & $<0,03$ \\
Den Helder & 0,02 & $<0,001$ & 0,001 & $<0,02$ \\
Griend & 0,01 & $<0,001$ & 0,02 & $<0,03$ \\
Mellum & 0,01 & $<0,001$ & 0,02 & $<0,01$ \\
Oldeoog & 0,01 & $<0,001$ & 0,01 & $<0,03$ \\
Scolt Head & 0,01 & 0,01 & $<0,03$ \\
\hline
\end{tabular}

In these samples telodrin was below the detection limit. It seems to have disappeared shortly after the first sampling in the summer of 1965. This may be shown in Table 4. However, in 1966 it was still present in fishes (Table 1), in terns' eggs (Table 2), and even in 1967 it was still found in dead eiderducks on the island of Vlieland.

The chemical firm, situated in the Rotterdam industrial area near the mouth of the river Rhine, was kept informed about the results of this study from the beginning, and elaborate measures were undertaken to prevent the release of insecticides by means of the waste water. The decline in the residues of telodrin found in Mytilus edulis, as shown in Table 4, may probably be regarded as the result of these precautions.

The firm does not produce only telodrin, but also dieldrin and endrin. The residues of the latter two insecticides found in Mytilus edulis might also have resulted from industrial pollution by the same source. It is, however, difficult to ascertain this, because of the possibility of environmental contamination by agricultural use - or 
Table 4

Residues of chlorinated hydrocarbon insecticides in mussels (Mytilus edulis) sampled at Scheveningen. DDE see comment in Table 1

\begin{tabular}{|ccccc|}
\hline Date & dieldrin & $\begin{array}{c}\text { Residue in ppm of body weight } \\
\text { telodrin }\end{array}$ & endrin & DDE \\
\hline August 1965 & 0,08 & 0,11 & 0,05 & $<0,01$ \\
January 1966 & 0,12 & $<0,07$ & 0,20 & $<0,06$ \\
August 1966 & 0,10 & $<0,003$ & 0,36 & $<0,04$ \\
January 1967 & 0,07 & $<0,03$ & 0,26 & $<0,07$ \\
August 1967 & 0,02 & $<0,007$ & 0,04 & $<0,02$ \\
\hline
\end{tabular}

misuse - in the basin of the river Rhine. To evaluate this, further work is planned to determine the degree of contamination higher up the river. The results of this and other studies in the same field will be reported in full detail elsewhere. The facts presented make it quite clear that even in the marine environment one has to be extremely carefull with the disposal of persistent chemicals, particularly of types which are being accumulated in plants and animals.

\section{SUMMARY}

1. Sandwich terns (Sterna sandvicensis) of a colony in the Dutch Wadden Sea, which were seen dying in tremors and convulsions, were analysed for their contents of chlorinated hydrocarbon insecticides. These proved to be present in considerable concentrations.

2. The concentrations found were compared to those present in chickens of hens, poisoned in the laboratory. The amounts present in the dying or dead Sandwich terns were high enough to cause their death.

3. Tern eggs from different coastal places in Ireland, Great Britain, The Netherlands and West Germany were sampled and analysed for these compounds. The amounts of dieldrin, telodrin and endrin in the eggs from the first two countries were much lower than those in the eggs from the last two ones. The amounts of DDE were quite the same.

4. Tern food fishes (Clupea sprattus, Clupea harengus and Ammodytes lanceolatus) were sampled in the Dutch Wadden Sea and analysed. They contained considerable amounts of chlorinated hydrocarbon insecticides.

5. Mussels (Mytilus edulis) were sampled at a series of locations alongside the Dutch coast. The highest concentrations of the insecticides were found on places near the mouth of the river Rhine. Also telodrin, an insecticide not used in Europe, was found.

6. A big insecticide producing industry near the mouth of the river Rhine was informed of these facts. Measures taken by this form resulted in a decrease of the amounts of telodrin in the coastal North Sea environment.

Acknowledgements: Tern eggs from Ireland, Great Britain and West Germany were obtained thanks to the help of Dr. D. Cabot, Dr. C. Walker, Dr. F. Goethe and Dr. W. PRZYGODDA, respectively. 


\section{LITERATURE CITED}

Butler, P. A., 1966. Pesticides in the marine environment. J. appl. Ecol. 3 (Suppl.), 253-259.

Koeman, J. H. \& Genderen, H. vaN, 1965. Some preliminary notes on residues of chlorinated hydrocarbon insecticides in birds and mammals in the Netherlands. Meded. LandbHogesch. OpzoekStns Gent 30, 1879-1887.

- 1966. Some preliminary notes on residues of chlorinated hydrocarbon insecticides in birds and mammals in the Netherlands. J. appl. Ecol. 3 (Suppl.), 99-106.

- Oskamp, A. A. G., Veen, J., Brouwer, E., Rooth, J., Zwart, P. \& Genderen, H. van, 1967 a. Pesticides as a factor in the mortality of the Sandwich tern (Sterna sandoicensis). Meded. LandbHogesch. OpzoekStns Gent 32 (in press).

- Oudejans, R. C. H. M. \& Huisman, E. A., 1967b. Danger of chlorinated hydrocarbon insecticides in birds' eggs. Nature, Lond. 215, 1094-1096.

Report of a new chemical hazard, 1966. New Scient. 32 (525), 612.

TelonRIN intoxicaties, 1965. Mededeling van de Veeartsenijkundige Dienst. Diergeneesk. Tijdschr, 90, 267-269.

\section{Discussion (by correspondence) following the paper by KOEMAN, VEEN, Brouwer, Huisman-De Brouwer \& Koolen}

KINNE: In regard to the toxicological significance of the insecticides mentioned, can you give more detailed information on the critical levels (both in the water and in body tissues) above which dangerous biological consequences may result?

KOOLEN: There is not much known about levels above which dangerous biological consequences may result. The concentrations in water of the various hydrocarbon insecticides, toxic for aquatic organisms in a direct way, have a range from 0.1 to 100 micrograms per litre $(\mathrm{ppb})$, depending on the insecticide and on the type of organism. The serious phenomena shown in this study are not due to direct, but to indirect intoxification. The insecticides are present in the water in a concentration far below the toxic level. However, they are lipophile, and concentrate in fat and fat-like substances, as present in living organisms. This is the first step on the way to a higher concentration. The following steps occur in the food chain, ending in animals feeding on fish. The concentrations of insecticides found in several organs and in the blood of the sandwich terns in this study, were in the order of 0.1 to $10 \mathrm{ppm}$. It is still not known, and a subject of further investigations, which concentration in the water might have caused those found in the terns.

KINNE: Are the insecticides in question subject to microbial degradation?

KOOLEN: It has been proved that there are circumstances under which several chlorinated hydrocarbon insecticides are converted to other compounds, by the action of living microorganisms or higher animals. Especially anaerobic digested sludge $\left(\mathrm{CH}_{4}\right.$ - and $\mathrm{H}_{2} \mathrm{~S}$-production) seems to have a rather big capacity in degradating insecticides (HILL, D. W. \& P. L. MCCARTHY 1967. Anaerobic degradation of selected chlorinated hydrocarbon insecticides. J. Water Poll. Contr. Fed. 39, 1259). But here remains an important question: what characteristics do the degradation products have? It has been proved that aldrin may be converted to dieldrin, and heptachlor to its epoxyde, both these products are used as insecticides also. Furthermore, circumstances in natural, aerated waters are quite different from those in the laboratory experiments. In many waters, also in the oceans far from civilisation, chlorinated hydrocarbons have been found, these must have circulated in the water during a long time. An important fact, found in the laboratory, is the possible conversion to hydrophile compounds; these have not been characterised untill now. The result of this may be, that the accumulation is stopped, which is of great importance, of course. But anyhow, in the case of the intoxified Sandwich terns along the Dutch coast microbial conversion, if present, has been insufficient. 